\title{
Effect of Aeration Treatment on Methylene Blue Removal Using TiO2-Zeolite
}

\author{
Nanda Alzeta Pratama*, Pedy Artsanti \\ Chemistry Department, Faculty of Science and Technology, UIN Sunan Kalijaga \\ J1. Marsda Adisucipto No 1 Yogyakarta 55281, Indonesia. Tel. +62-274-540971, Fax. +62-274-519739 \\ Email: nandaalzeta@gmail.com
}

\begin{abstract}
Effect of aeration treatment on Methylene Blue (MB) removal using $\mathrm{TiO}_{2}$-Zeolite has been investigated. The $\mathrm{TiO}_{2}$-Zeolite was prepared by mixing activated zeolite and $\mathrm{TiO}_{2}$ in absolute ethanol. This composite was characterized using Fourier Transform Infrared (FT-IR) and X-Ray Diffraction (XRD). The MB removal was monitored spectrophotometrically. The effect of contact time, composite mass, and aeration treatment on $\mathrm{MB}$ removal was observed. Characterization results showed that there was interaction between $\mathrm{TiO}_{2}$ and $\mathrm{SiO} / \mathrm{AlO}$ of zeolite. The observation of aeration treatment using oxygen exhibited significant improving on MB removal.
\end{abstract}

Keywords: Aeration, Composite, Methylene Blue, Removal, $\mathrm{TiO}_{2}$-Zeolit

\section{INTRODUCTION}

Along with the increase in population, the textile industry in Indonesia continues to grow. The rapid development of the textile industry has a positive impact on increasing employment. In addition to providing many benefits for human life, the development of the textile industry has a negative impact on the environment. This is because in textile production it always produces waste. The waste of textile industry has a high content of dye. Dyes in the textile industry are organic compounds that are not biodegradable and toxic (Manurung et al., 2004).

Reactive dyes are dyes which are widely used for dyeing of textile products. Various methods have been carried out to treat the waste and the results are quite effective. Some of the methods are adsorption, biodegradation, chlorination and ozonation. However, this method requires large operational cost making it is less effective to implement in Indonesia. Another method that is widely used is a combination of coagulation, oxidation, electrochemistry, osmosis and adsorption. However, these methods have a weakness, which basically only acts to transfer pollutants from wastewater to other media, causing new problems (Wijaya et al., 2006).

Fujishima and Honda (1972) showed that photodegradation using photocatalyst emerged as one of the alternative of waste treatment technology. Photocatalyst is a chemical process involving light and a catalyst. $\mathrm{TiO}_{2}$ which can function as a semiconductor is often used as a photocatalyst because it is available and safe to use. However, the high photocatalytic activity of $\mathrm{TiO}_{2}$ does not appear to be compatible with its ability to absorb the target compounds. According to Fatimah et al (2005), the photocatalytic activity of $\mathrm{TiO}_{2}$ can be enhanced through the use of the supporting materials, one of which is acid-activated natural zeolite.

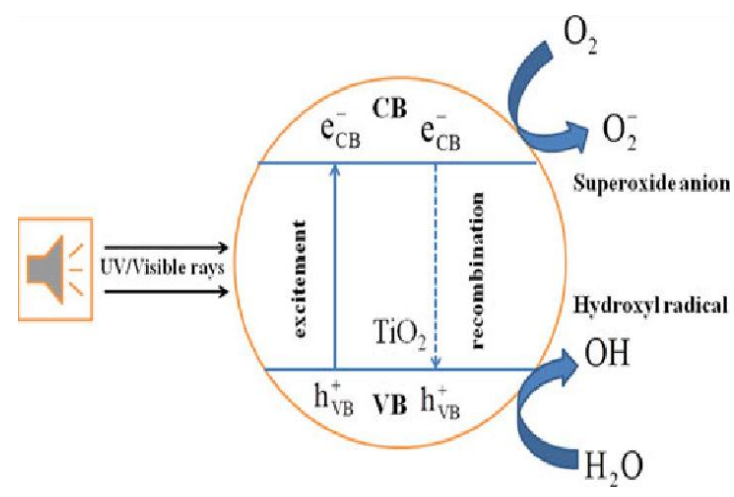

Figure 1. The photocatalytic activity of $\mathrm{TiO}_{2}$ under UV irradiation (Krishna et al., 2013).

Upon UV irradiation, $\mathrm{TiO}_{2}$ mainly absorbs UV photons leading to the generation of electrons and holes on the surface. A photon having energy equal to or higher than that of the band gap moves an electron from the valence band to the conduction band leaving behind a hole in the valence band. The photogenerated electrons and holes either recombine or migrate to the surface to react with contaminant adsorbed on the surface. The hole in the valence band (VB) reacts with $\mathrm{H}_{2} \mathrm{O}$ adsorbed on the surface to produce hydroxyl radicals, and the electron in the conduction band (CB) reduces $\mathrm{O}_{2}$ to produce superoxide ions $\left(\mathrm{O}_{2}{ }^{-}\right)$. Hydroxyl radicals and superoxide ions are particularly reactive to decompose organic compounds present on the $\mathrm{TiO}_{2}$ surfaces because of their strong oxidation power (Krishna et al., 2013).

Aeration is one way to enhanced the dissolved oxygen of water. In theory, the use of pure oxygen aeration will help in the process of photodegradation of organic compounds. According to the theory of photocatalytic activity of $\mathrm{TiO}_{2}$ under UV irradiation (Figure.1), the more oxygen around $\mathrm{TiO}_{2}$, the more anionic superoxide will be produced. This will increase 
the degradation of $\mathrm{MB}$ as a target compound and lead to improve on MB removal.

\section{MATERIALS AND METHODS}

\section{Materials}

The tools that using for $\mathrm{TiO}_{2}$-Zeolite preparation are glassware, analytical scale, buchner pump, hot plate, magnetic stirrer, spoon glass, $\mathrm{pH}$ meter, regulator, oxygen tube, centrifuge, furnace, UV- blacklight reactor, and 106 micron sieve. While the characterization of the composite using X-ray Diffraction (XRD) and Fourier Transform Infrared (FTIR). The monitoring of MB removal is using UVVis Spectrophotometer and 20-D Spectronic.

The natural zeolite used in this research was obtained from Wonosari, GunungKidul, Yogyakarta. The other materials using for research are $\mathrm{TiO}_{2}$ p.a Merc, Hydrochloric acid ( $\mathrm{HCl})$ p.a Merc, whatman-42 filter paper, millipore paper, oxygen, distilled water and Methylene Blue (MB).

\section{Zeolite Activation}

Fifty grams of natural zeolite which passed the sieve with a 106 micron diameter was soaked in $100 \mathrm{~mL}$ of $3 \mathrm{M} \mathrm{HCl}$, then stirred the mixture for 24 hours using magnetic stirrer at $90^{\circ} \mathrm{C}$. After that, the mixture was filtered using filter paper and washed using distilled water until the $\mathrm{pH}$ of filtrate is equal to the $\mathrm{pH}$ of distilled water. Then zeolite was calcined on $450^{\circ} \mathrm{C}$ for 3 hours and characterized using XRD and FT-IR.

\section{The Preparation of $\mathrm{TiO}_{2}$-Zeolite Composite}

Eight grams of activated zeolite and $1.4 \mathrm{~g} \mathrm{TiO}_{2}$ were mixed in beaker glass. The mixture was dissolved in 10 $\mathrm{mL}$ of absolute ethanol and stirred for 5 hours. This mixture was then dried by heating in oven at $120^{\circ} \mathrm{C}$ for 5 hours. The solid then grinded and sieved with 106 micron sieve. Finally, the solid was calcined at $500^{\circ} \mathrm{C}$ for 5 hours. By using this procedure, the solid obtained was assigned to as composite of $\mathrm{TiO}_{2}$-Zeolite. This composite was characterized using Fourier Transform Infrared (FT-IR) and X-Ray Diffraction (XRD).

\section{Photodegradation of Methylene Blue}

Photodegradation experiments were conducted in a batch reactor under UV light. Photodegradations were engaged by dispersing a certain amount of $\mathrm{TiO}_{2}$-Zeolite composite into $\mathrm{MB}$ solution followed by stirring and UV irradiation.

1. Optimum contact time determination.

The determination of optimum contact time was conducted by dispersing $40 \mathrm{mg}$ of $\mathrm{TiO}_{2}$-Zeolite composite into $25 \mathrm{~mL}$ of $40 \mathrm{ppm} \mathrm{MB}$ solution. The experiments were observed at $30,45,60,75$, and 90 minutes contact time with UV irradiation. This experiment was also performed a control by dispersing the same amount of $\mathrm{TiO}_{2}$-Zeolite composite into the same volume and concentration of MB solution at the same varied of contact time without UV irradiation. Another control was performed by dispersing $40 \mathrm{mg}$ of activated zeolite into the same volume and concentration of MB solution at the same varied of contact time with UV irradiation. The MB removal was determined using UV-Vis Spectrophotometer and 20-D Spectronic.

2. Optimum composite mass determination.

The determination of optimum composite mass was conducted by dispersing 20,40 , and $60 \mathrm{mg}$ of $\mathrm{TiO}_{2-}$ Zeolite composite into $25 \mathrm{~mL}$ of $40 \mathrm{ppm} \mathrm{MB}$ solution. The experiments were observed at the optimum contact time. This observation was also performed the controls using $\mathrm{TiO}_{2}$-Zeolite composite (without UV irradiation) and activated zeolite (with UV irradiation). The MB removal was determined using UV-Vis Spectrophotometer and 20-D Spectronic.

3. Aeration treatment effect.

The effect of aeration was observed by diffusing of oxygen into $25 \mathrm{~mL}$ of $70 \mathrm{ppm} \mathrm{MB}$ solution at varied of oxygen diffusing time; 10, 20, and 30 minutes, respectively. These experiments were conducted using the optimum mass of $\mathrm{TiO}_{2}$-Zeolite for 30 minutes contact time with UV irradiation. The MB removal was determined using UV-Vis Spectrophotometer.

\section{RESULTS AND DISCUSSION}

\section{Materials Characterization}

Pattern of X-ray diffraction provides information about the type of the mineral arrange in materials (natural zeolit (ZA), activated zeolit ( $\mathrm{ZH})$, and $\mathrm{TiO}_{2}$-Zeolite composite) and the cristallinity of the materials. Figure 2 showed the characteristics of $\mathrm{ZA}, \mathrm{ZH}$, and $\mathrm{TiO}_{2^{-}}$ Zeolite composites.

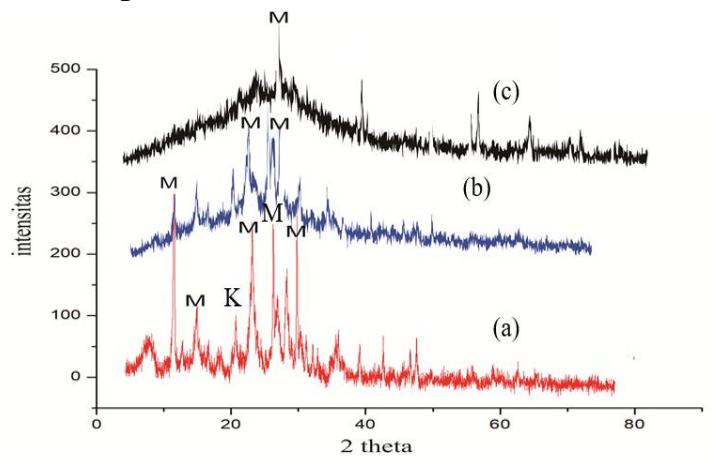

Figure 2. Diffractogram (a) ZA and (b) $\mathrm{ZH}$ (c) Composite $\mathrm{TiO}_{2}-\mathrm{Zeolite}$.

Figure 2 shows that the main composition of the natural zeolit $(\mathrm{ZA})$ is mordenite. This is indicated by specific peak of material that appear on the $2 \theta=9,75^{\circ}$; $13,37^{\circ} ; 19,48^{\circ} ; 22,20^{\circ} ; 25,54^{\circ} ; 26,16^{\circ} ; 27,60^{\circ}$ dan $29,81^{\circ}$. These specific peaks are confirmed by Wijaya (2006). The diffractogram of activated zeolit $(\mathrm{ZH})$ shows no significant difference with ZA, but it shows a 
decrease in intensity, that means decreasing of crystallinity of $\mathrm{ZH}$. It apparently due to the activation process using $3 \mathrm{M} \mathrm{HCl}$ that escalate dealumination process resulting increasing the ratio of $\mathrm{Si} / \mathrm{Al}$ (Lestari, 2010).

To ensure the presence of $\mathrm{TiO}_{2}$ in the $\mathrm{TiO}_{2}$-Zeolite composite, the $\mathrm{X}$-ray diffraction analysis on $\mathrm{TiO}_{2}$ and $\mathrm{TiO}_{2}$-Zeolite composite was made. The diffraction pattern of $\mathrm{TiO}_{2}$ and $\mathrm{TiO}_{2}$-Zeolite composite are shown in Figure 3. X-Ray diffraction provides information about the types of $\mathrm{TiO}_{2}$ crystals. The diffractogram of $\mathrm{TiO}_{2}$ (a) was compared with the XRD data of various types of crystals such as anatase, rhutile and brookite in JCPDS (2001). Figure 3, especially the specific peaks that appear on the $2 \theta=37,55^{\circ} ; 47,80^{\circ}$; and $53,61^{\circ}$ shows the reflection of $\mathrm{TiO}_{2}$. In the $\mathrm{TiO}_{2}$-Zeolite composite (b), it can be observed that the high diffraction intensity appeared at peak on the $2 \theta=$ $25,06^{\circ}$, indicate the specific peak of mordenite.

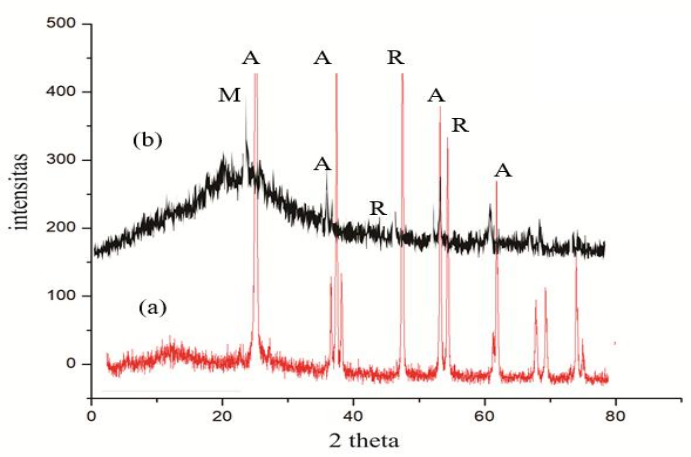

Figure 3. Diffractogram (a) $\mathrm{TiO}_{2}$ Degussa and (b) Composite $\mathrm{TiO}_{2}$ zeolite.

The functional groups that present in activated zeolite and $\mathrm{TiO}_{2}-$ Zeolite composite were studied using the FTIR spectroscopy. Figure 4 shows the comparison of FTIR spectra of activated zeolite and $\mathrm{TiO}_{2}-$ Zeolite composite. From Figure 4, it can be observed that the samples of activated zeolite and $\mathrm{TiO}_{2}$-Zeolite composite exhibited similar FTIR spectra characteristics of zeolite. This indicated that zeolite is high suitable to act as $\mathrm{TiO}_{2}$ immobiliser, as the structure is not affected by impregnating of $\mathrm{TiO}_{2}$.

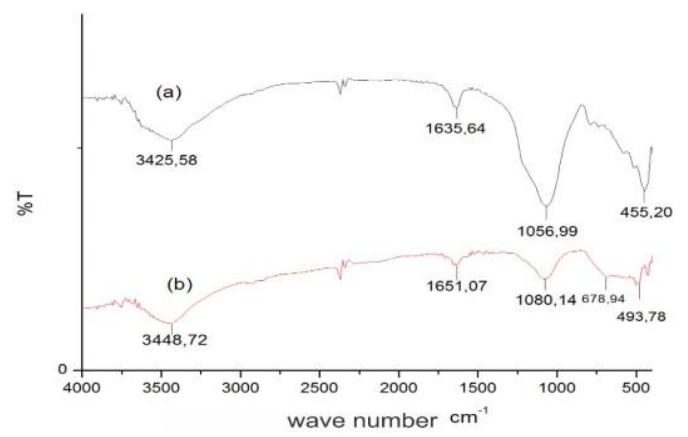

Figure 4. FT-IR spectra (a) Activated Zeolite and (b) Composite $\mathrm{TiO}_{2-}$ Zeolite.
In Figure 4 there is a spectral difference between the spectra of $\mathrm{TiO}_{2}$-Zeolite composite (b) and activated zeolite (a). The difference is pointed out at the presence of the band at $678.94 \mathrm{~cm}^{-1}$ in $\mathrm{TiO}_{2}$-Zeolite composite spectra which were not observed in activated zeolite spectra. The band is probably associated with $\mathrm{TiO}_{2}$ as reported by Chamidah (2016) that $\mathrm{TiO}_{2}$ band showed at $694.37 \mathrm{~cm}^{-1}$. This characterization results indicated that there was interaction between $\mathrm{TiO}_{2}$ and $\mathrm{SiO} / \mathrm{AlO}$ of zeolite.

\section{Photodegradation of Methylene Blue}

\section{Optimum Contact Time Determination}

The contact time is an important point in photocatalytic water treatment processes. The optimum contact time enables the maximum photocatalytic activity. The results of the optimum contact time determination are showed in Figure 5. The results of the treatment using $\mathrm{TiO}_{2}$-Zeolite composite with UV irradiation (Figure 5(a)) show that the percentage removal of $\mathrm{MB}$ increases with the increasing of contact time and significantly decreases in the removal of $\mathrm{MB}$ when passing the optimum point of contact time. The highest percentage removal is pointed at 75 minutes contact time resulting in $91.10 \%$ removal.

Control experiment (Figure 5(b)) shows that in the absence of UV irradiation, the removal of MB was relatively low. The optimum contact time of this control experiment was 45 minutes resulting $80.91 \%$ MB removal. According to Wijaya (2006), this phenomenon indicates the adsorption process, since there is no source of light (photons). In the other control experiment with the absence of $\mathrm{TiO}_{2}$, the activated zeolite reached the optimum contact time at 45 minutes resulting $86.13 \% \mathrm{MB}$ removal. Both of these control experiments show the evidence of lower $\mathrm{MB}$ removal in comparison with the $\mathrm{MB}$ removal using $\mathrm{TiO}_{2}$-Zeolite composite in the presence of $\mathrm{UV}$ irradiation.

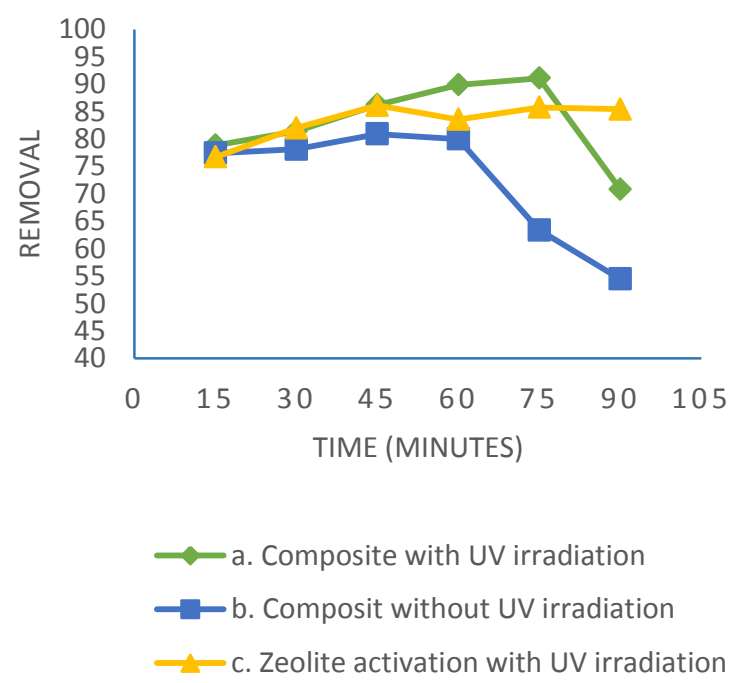

Figure 5. The results of MB removal at the optimum contact time determination. 
In order to ensure that $\mathrm{MB}$ removal by $\mathrm{TiO}_{2}$-Zeolite composite was caused by photodegradation mechanism, spectrophotometric analysis to the treated MB solution was conducted. Figure 6 shows that the absorbance of characteristic spectra are decreased as indication of adsorption process. Furthermore, the UVVisible spectra of treated MB solutions by using $\mathrm{TiO}_{2^{-}}$ Zeolite composite at the presence of UV irradiation
(Figure 6 (a)) exhibit the lowest absorbance. This observation also brings out the change in color of the treated solution, becomes clearer (data not shown). It can be stated that apparently both of these phenomenon indicate the adsorption and degradation process of $\mathrm{MB}$ molecule. This is confirmed by Wang S.L et.al., (2011) that observed the similar phenomenon.

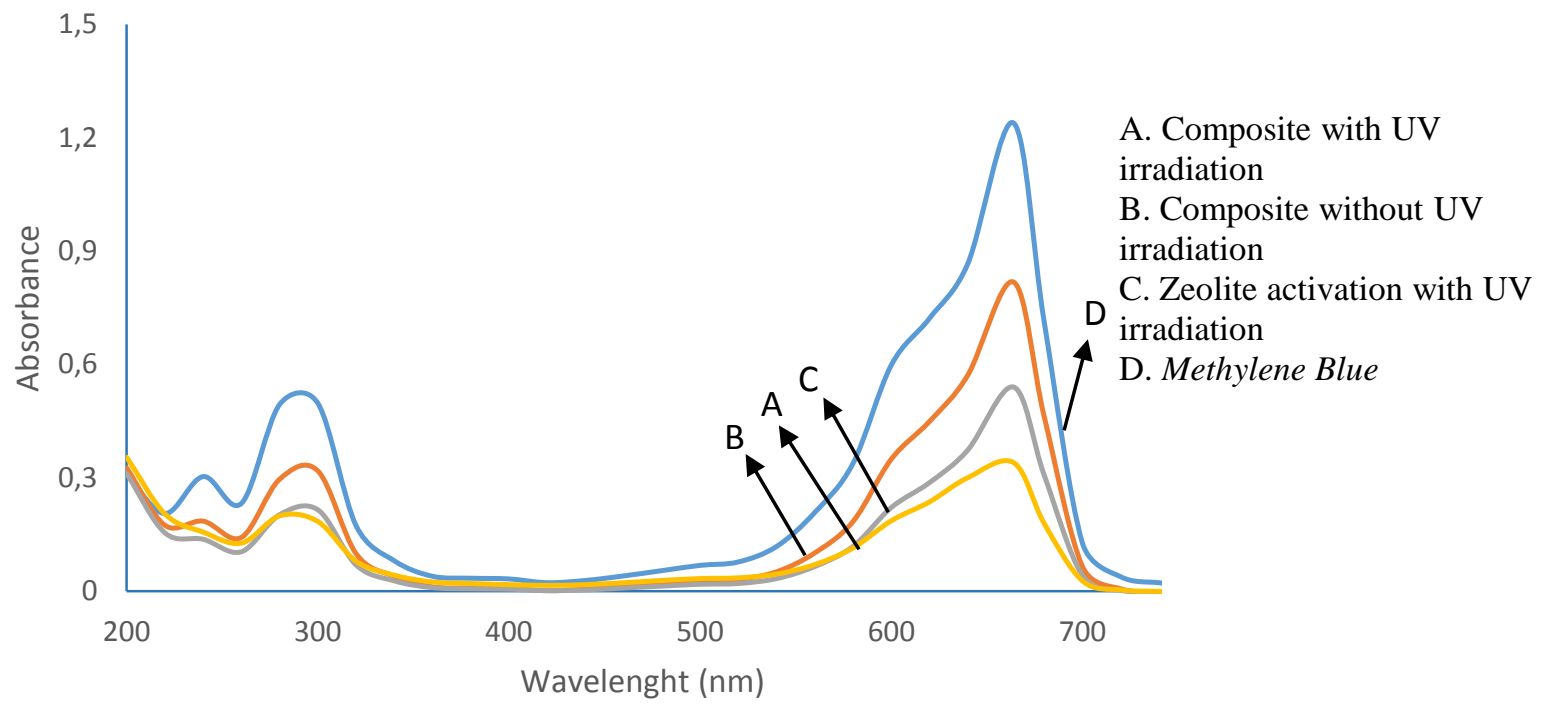

Figure 6. UV-Visible spectra of treated MB solutions at the optimum time.

\section{Optimum Composite Mass Determination}

The optimum composite mass enables the maximum photoactivity while preventing the unnecessary excess use of composite. The results of the optimum composite mass determination are showed in Figure 7.

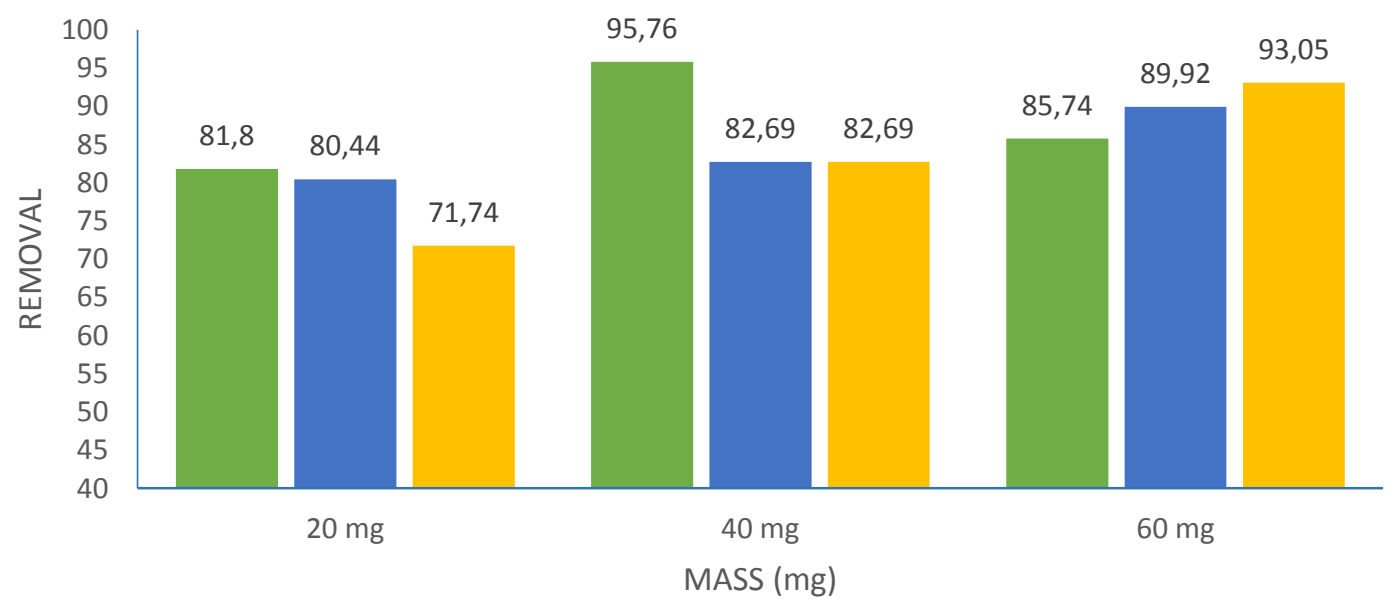

- Composite with UV irradiation

- Composite without UV irradiation

Zeoliteactivation with UV irradiation

Figure 7. The results of MB removal at the optimum mass determination. 
Primarily the increase in MB removal when the $\mathrm{TiO}_{2}$-Zeolite composites loading was increased from $20 \mathrm{mg}$ to $40 \mathrm{mg}$ was attributed to the higher number of active sites and more reactive radicals available for surface reaction. However, the reduction in $\mathrm{MB}$ removal of $\mathrm{TiO}_{2}-$ Zeolite composites was observed at higher composite loadings $(60 \mathrm{mg})$ owing to the increasing cloudiness in the reaction solution that prevents penetration from UV irradiation. Similar phenomenon was observed by M.N. Chong et al (2014). The calculation of maximum MB removal that obtained in this experiment was $0.023 \mathrm{mg}$ per $1 \mathrm{mg}$ of composite material.
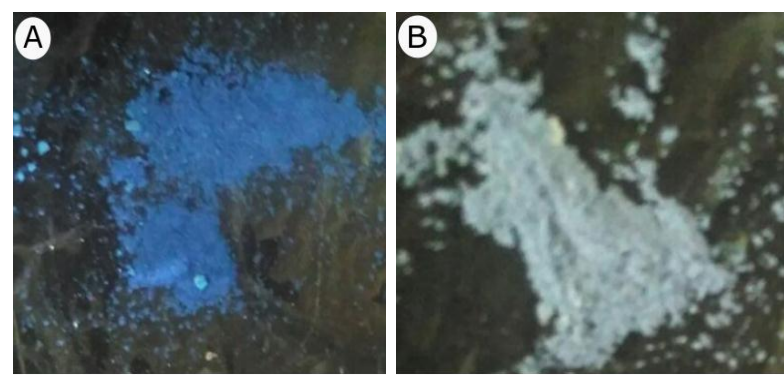

Figure 8. The color of the materials that had been used to treat the MB solution in this experiment (a) Activated Zeolite with UV irradiation (b) $\mathrm{TiO}_{2}$-Zeolite composite with UV irradiation.

The color of the materials that have been used to treat the MB solution in this experiment were compared and photographed as data, Figure 8 . In the photograph (Figure 8), it is clear that activated zeolite exhibits a strong blue color while $\mathrm{TiO}_{2}$-Zeolite composite exhibits significant different color, white with a bluish color. The blue color of activated zeolite after been used to treat the MB solution indicates that MB molecules was adsorbed, changing the brownish color of activated zeolite into blue color. In contrast, the composite of $\mathrm{TiO}_{2}$-Zeolite exhibits white with a bluish color. This significant different color of the materials that had been used to treat the MB solution reveals a strong evidence of degradation process of $\mathrm{MB}$ molecule when treated using $\mathrm{TiO}_{2}$-Zeolite composite at the presence of $\mathrm{UV}$ irradiation. Similar phenomenon was observed and confirmed by Wang S.L et al (2011). In conclusion, it can be stated that both adsorption and photodegradation process contributed on MB removal in this experiment.
On the whole, it is clear that photodegradation process in this experiment requires both, photocatalyst material $\left(\mathrm{TiO}_{2}\right)$ and photon source (UV irradiation). The absence of photocatalyst material or photon source reveals no photodegradation process. Degradation of MB by using $\mathrm{TiO}_{2}$ is refer to reduction-oxidation reactions generated from absorption of photons by $\mathrm{TiO}_{2}$ that leads photoexication: the formation of electronpositive hole pairs. If charge separation is maintained, the electron and hole may migrate to the catalyst surface where they participate in redox reactions with sorbed species. Specially, $\mathrm{h}^{+}$vb may react with surfacebound $\mathrm{H}_{2} \mathrm{O}$ or $\mathrm{OH}^{-}$to produce the hydroxyl radical and $\mathrm{e}_{\mathrm{cb}}$ is picked up by oxygen to generate superoxide radical anion $\left(\mathrm{O}_{2}{ }^{\mathbf{0}}\right)$, as indicated in the following reaction (Haque et al., 2012):

$$
\begin{aligned}
& \mathrm{TiO}_{2}+\mathrm{hv} \longrightarrow \mathrm{TiO}_{2}\left(\mathrm{e}^{-}+\mathrm{h}^{+}\right) \\
& \left(\mathrm{H}_{2} \mathrm{O} \Leftrightarrow \mathrm{H}^{+}+\mathrm{OH}^{-}\right)+\mathrm{h}^{+} \longrightarrow \mathrm{O}_{2}^{\mathbf{o}^{-}} \longrightarrow-\mathrm{OH}+\mathrm{H}^{+} \\
& \mathrm{O}_{2}+\mathrm{e}^{-} \longrightarrow \mathrm{C}^{-}
\end{aligned}
$$

It has been suggested that the hydroxyl radical ($\mathrm{OH})$ and superoxide radical anions $\left(\mathrm{O}_{2}{ }^{\mathbf{0}}\right)$ are the primary oxidizing species in the photocatalytic oxidation processes

$-\mathrm{OH}+\mathrm{MB} \longrightarrow \mathrm{CO}_{2}+\mathrm{H}_{2} \mathrm{O} \quad$ (degradation
$\begin{aligned} & \text { products) } \\ & \mathrm{O}_{2}^{\mathbf{0}-}+\mathrm{MB} \\ & \text { products) }\end{aligned}$

\section{Aeration Treatment Effect}

Aeration treatment was done to increase the amount of dissolved oxygen in the MB solution. Pure oxygen was diffused into a solution of $\mathrm{MB}$ before the photodegradation process was carried out. This treatment was expected to improve the performance of $\mathrm{TiO}_{2}$-Zeolite composites to degrade $\mathrm{MB}$ when photodegradation was carried out. Dissolved oxygen would interact with $\mathrm{e}_{\mathrm{cb}}$ on the surface of $\mathrm{TiO}_{2}$-Zeolite and produce superoxide radical anion $\left(\mathrm{O}_{2}{ }^{\mathbf{0}}\right)$. The more dissolved oxygen, the more superoxide radical anion $\left(\mathrm{O}_{2}{ }^{\mathbf{o}}\right)$ formed. The synergy of this condition was highly expected to maximize the process of $\mathrm{MB}$ photodegradation resulting greater MB removal. The results of this experiment are showed in Table 1.

Table 1. Aeration treatment - methylene blue photodegradation.

\begin{tabular}{llllll}
\hline Diffusing Time & Absorbance & C final (ppm) & Removal (\%) & MB initial (mg) & MB removal (mg) \\
\hline $\mathbf{1 0}$ & 0,908 & 8,405 & 87,99 & 1,75 & 1,53 \\
$\mathbf{2 0}$ & 0,657 & 6,075 & 91,32 & 1,75 & 1,59 \\
$\mathbf{3 0}$ & 0,441 & 4,0696 & 94,18 & 1,75 & 1,64 \\
\hline
\end{tabular}

According to Tabel 1, it is clear that the enhancement of photodegradation process can be attained using aeration treatment. The total time used in the maximum $\mathrm{MB}$ removal in this type of experiment was 60 minutes consisting of 30 minutes of oxygen diffusing time plus 30 minutes of contact time for 
photodegradation process using $\mathrm{TiO}_{2}$-Zeolite composite at the presence of UV irradiation, resulting $0.041 \mathrm{mg}$ $\mathrm{MB}$ removal per $1 \mathrm{mg}$ composite. This is much more effective and efficient in compare to the former experiment (I and II). The total time consumed in the former experiment that resulting maximum $\mathrm{MB}$ removal was 75 minutes (optimum time) using $\mathrm{TiO}_{2-}$ Zeolite composite with UV irradiation. The former experiment was only removed $0.023 \mathrm{mg}$ of $\mathrm{MB}$ per 1 mg composite. In conclusion, it can be stated that aeration treatment using oxygen bringing out significant improving on MB removal.

\section{CONCLUSIONS}

Composite of $\mathrm{TiO}_{2}$-Zeolite was successfully prepared. Characterization results of $\mathrm{TiO}_{2}$-Zeolite composite using XRD and FT-IR show that there was interaction between $\mathrm{TiO}_{2}$ and $\mathrm{SiO} / \mathrm{AlO}$ of zeolite. The results of MB photodegradation demonstrated that the MB treatment using $\mathrm{TiO}_{2}$-Zeolite composite with UV irradiation showed an increase in the percentage of $\mathrm{MB}$ removal with increased contact time and significantly decreased in MB removal when it passed the optimum contact time. The optimum composite mass was also enabling the maximum photoactivity while preventing the unnecessary excess use of composite. The observation of aeration treatment using oxygen in this experiment revealed significant improving on $\mathrm{MB}$ removal.

\section{ACKNOWLEDGEMENTS}

The authors acknowledge the Chemistry Department of Faculty of Science and Technology, State Islamic University Sunan Kalijaga, Yogyakarta, Indonesia for providing the opportunity of this research work. We also acknowledge sincere thanks to Dr. Imelda Fajriati and Khamidinal, M.Si for their advices.

\section{REFERENCES}

Ardiani, P. 2010. Efektifitas Katalis TiO2 dengan Penambahan $\mathrm{Mg}(\mathrm{OH}) 2.5 \mathrm{H} 2 \mathrm{O}$ pada Fotodegradasi Zat Warna Rhodamine B. Fakultas MIPA Univesitas Sebelas Maret. Surakarta

Chamidah, T.A., \& Arsanti, pedy. 2016.peningkatan Efektifitas Fotodegradasi Congo Red Menggunakan Komposit TiO ${ }_{2}$-Zeolit Dengan Aerasi Sederhana. Yogyakarta: Prosiding Seminar Nasional Kimia UNY

Choung, M.N et al,. 2015. Synthesis, characterisation and application of $\mathrm{TiO} 2-$ zeolite nanocomposites for the advanced treatment of industrial dye wastewater, Journal of the Taiwan Institute of Chemical Engineers. Retrieved From http://dx.doi.org/10.1016/j.jtice.2014.12.013

Fatimah, I., Sugiharto, E., Wijaya, K., Tahir, I., Kamalia., 2005. Titan Dioksida Terdispersi Pada Zeolit Alam (TiO $\mathrm{T}_{2}$ Zeolit) Dan Aplikasinya Untuk Fotodegradasi Congo Red, Fakultas Matematika dan Ilmu Pengetahuan Alam, Universitas Islam Indonesia, Yogyakarta

Fatimah, I., Wijaya, K., 2005, Sintesis $\mathrm{TiO}_{2} /$ Zeolit Sebagai Fotokatalis Pada Pengolahan Limbah Cair Industri Tapioka Secara Adsorpsi-Fotodegradasi. Jurusan Kimia FMIPA UII, Yogyakarta

Fujisima, A,K.; Honda, K. Electrochemical Photolysis of water at a Semiconductor Electroda, Nature, 1972, 238.

Hamdan, H., 1992, Introduction to Zeolites, Synthesis, Characterization and Modification, Universiti Technologi Malaysia, Kuala Lumpur

Haque, Malik Mohibbul., Bahnemann, detlef \& Muneer, Mohammad. 2012. Photocatalytic Degradation of Organic Pollutants: Mechanisms and Kinetics. In Tech. Doi: $10.5772 / 34522$

Krisna, M.G., Vinjanampati, M., \& Purkayastha,D.D. 2013. Metal oxide thin films and nanostructures for self-cleaning applications: current status and future prospects. Eur. Phys. J. Appl. Phys. (2013) 62: 30001; DOI:10.1051/epjap/2013130048

Lestari, Y. D., 2010, Kajian Modifikasi dan Karakterisasi Zeolit Alam dari Berbagai Negara, Prosiding, Seminar Nasional Kimia dan Pendidikan Kimia UNY

Lestari, Y. D., 2015, Degradasi Methylen Blue Menggunakan Fotokatalis TiO2-N/Zeolit Dengan Sinar Matahari. Fakultas Matematika dan Ilmu Pengetahuan Alam, Universitas Brawijaya, Malang

Lian, W.S., Fen, F.Y., Yong, Y.,Zi,L.J., Ping,D.A., Xiao, R., \& ping, H.Y. 2011. Catalysis of organic pollutant photodegradation by metal phthalocyanines immobilized on $\mathrm{TiO}_{2} @ \mathrm{SiO}_{2}$. Chinese $\mathrm{Sci}$ Bull (Chinese Science Bulletin). Vol.56 No.10: 969-976; doi: 10.1007/s11434-010-4280-3

Manurung, R., Hasibuan, R., dan Irvan., 2004. Perombakan zat warna Azore aktif secara Anaerob-aerob, $e$-Repository USU.

Wijaya, K., Surgiharto, E., Fatimah, I., Sudiono, S., dan Kurniyasih, D., 2006, Ultilisasi TiO2-Zeolit dansinar UV untuk Fotodegradasi Zat Warna Congo Red, Berkala. Yogyakarta: MIPA UGM. 